Robert Szponder

Uniwersytet Papieski Jana Pawła II w Krakowie

\title{
Regulacja prawna zaręczyn w Polsce
}

Instytucja zaręczyn nie zawdzięcza swojego powstania chrześcijaństwu. W prawie świeckim zaręczyny były znane zarówno prawu rzymskiemu, gdzie stanowiły niekonieczną umowę przedwstępną do małżeństwa (sponsalia), jak i prawom plemiennym, np. germańskim, w których były koniecznym elementem poprzedzającym zawarcie związku małżeńskiego ${ }^{1}$. Zaręczyny występowały również w prawie Mojżeszowym, w którym także odgrywały doniosłą rolę 2 . Zainteresowanie chrześcijaństwa małżeństwem spowodowało, że przepisy dotyczące zaręczyn pojawiły się w prawie kanonicznym. W rezultacie instytucja ta była regulowana dwutorowo - zarówno prawem kanonicznym, jak i świeckim.

\section{Zaręczyny w dawnym prawie polskim}

Zaręczyny (zrękowiny) były znane dawnemu prawu zwyczajowemu. Wywodziły się ze zmówin, umowy przedślubnej zawieranej pomiędzy rodzinami przyszłych nowożeńców. Pośrednikiem była osoba zwana dziewosłębem. Zmówiny obejmowały zobowiązanie do zawarcia małżeństwa w przyszłości oraz ustalenie warunków materialnych. Przy zmówinach narzeczony wręczał ojcu panny młodej niewielką sumę pieniężną lub przedmiot, np. obrączkę. Taki symboliczny zadatek zastąpił dawną cenę kupna żony. W zamian narzeczony otrzymywał od ojca panny młodej przedmiot symbolizujący zobowiązanie

Por. W. Abraham, Forma zawarcia zaręczyn i małżeństwa, Lwów 1909, s. 6-7; S. Biskupski, Prawo małżeńskie Kościoła Rzymskokatolickiego, Warszawa 1956, s. 78-79.

2 Por. T. Gromnicki, Forma zawierania zaręczyn i małżeństw, Kraków 1910, s. 4. 
do oddania córki za mąż, np. laskę lub różdżkę. Po zmówinach następował ślub właściwy, tzw. zdawiny, a następnie przenosiny (wprowadzenie się panny młodej do domu męża) oraz pokładziny (skonsumowanie małżeństwa). Od xII wieku, pod wpływem Kościoła, zmówiny przekształciły się w zaręczyny³.

Zaręczyny były zawierane przez narzeczonych lub ich rodziców nawet wbrew woli przyszłych małżonków. Zwyczajowo trwały do około czterech lat. Odbywały się poprzez wymianę: dziewczyna wręczała mężczyźnie wianek, a on wręczał jej pierścień. Czasem dochodziło następnie do wymiany zwrotnej dziewczyna odbierała wianek, a mężczyzna otrzymywał z powrotem pierścień. Istotnym elementem zaręczyn było poczynienie ustaleń co do kwestii majątkowych, takich jak określenie wysokości posagu czy wiana. Zerwanie zaręczyn skutkowało odpowiedzialnością odszkodowawczą. Z czasem, pod wpływem ustawodawstwa kościelnego, przy zaręczynach zaczął być obecny proboszcz ${ }^{4}$.

W okresie I Rzeczpospolitej regulacja dotycząca zaręczyn, potr aktowanych jako umowa, znalazła się po raz pierwszy w projekcie kodeksu Andrzeja Zamojskiego z 1778 roku.

\subsection{Okres rozbiorów}

Ze względu na podział pomiędzy państwa zaborcze, na ziemiach polskich obowiązywało pięć porządków prawnych. Stan ten utrzymywał się także w okresie dwudziestolecia międzywojennego oraz w pierwszych latach powojennych. Dzięki pracom powołanej w 1919 roku Komisji Kodyfikacyjnej dochodziło do stopniowej unifikacji poszczególnych dziedzin prawa. Proces ten zakończył się ostatecznie w latach 40. $\mathrm{xx}$ wieku.

Spośród obcych systemów prawnych najmniejsze znaczenie miało prawo węgierskie obowiązujące na Spiszu i Orawie. Ze względu na niewielkie znaczenie jest ono pomijane ${ }^{5}$.

Na terenie dawnego Księstwa Warszawskiego, a potem Królestwa Kongresowego, obowiązywał od 1808 roku Kodeks Napoleona z 1804 roku. Nie zawierał on regulacji dotyczącej zaręczyn. Nie oznaczało to jednak, że nie były one w ogóle znane porządkowi prawnemu. Orzecznictwo francuskie niejednokrotnie zajmowało się skutkami zaręczyn, wskazując, że nie mogą

3 Por. S. Płaza, Historia prawa w Polsce na tle porównawczym, Cz. I. X - XVIII w., Kraków 2002, s. 230.

${ }_{4}$ Por. H. Konic, Prawo małżeńskie w Królestwie Kongresowym, Warszawa 1924, s. 56; S. Biskupski, Prawo..., dz. cyt., s. 8o; S. Dąbkowski, Polskie prawo prywatne, t. 1, Warszawa 1910, s. 345-347.

5 Prawo małżeńskie obowiązujące na Spiszu i Orawie zostało przedstawione w opracowaniu: M. Allerhand, Prawo małżeńskie obowiązujące na Spiszu i Orawie, Lwów 1926. 
one zostać zabezpieczone karą umowną za zerwanie oraz że strona zrywająca zaręczyny może ponosić odpowiedzialność odszkodowawczą ${ }^{6}$. Jako źródła tej odpowiedzialności wskazywano dwie podstawy prawne: art. $1382 \mathrm{KN}$ statuujący ogólną odpowiedzialność odszkodowawczą za niedotrzymanie zobowiązania oraz art. $1142 \mathrm{KN}$, dotyczący przerodzenia się odpowiedzialności za niewykonania zobowiązania czynienia w odpowiedzialność odszkodowawczą ${ }^{7}$ O ile jednak Kodeks Napoleona obowiązywał aż do lat 30. (prawo zobowiązań) i 40. $\mathrm{xx}$ wieku (prawo spadkowe i rzeczowe), to rewolucyjny - ze względu na wprowadzenie instytucji świeckiego małżeństwa zawieranego przed urzędnikiem stanu cywilnego i rozwodu oraz jurysdykcji sądów świeckich w sprawach małżeńskich - charakter prawa małżeńskiego sprawił, że nie zostało ono zaakceptowane w Polsce. Przez pierwsze 10 lat obowiązywania kodeksu zawarto tylko trzy małżeństwa w formie wyłącznie świeckiej oraz orzeczono siedem rozwodów ${ }^{8}$. Przywrócenie religijnego charakteru prawa małżeńskiego nastąpiło w latach 20. XIX wieku poprzez dodanie rozdziału dotyczącego małżeństwa do kodeksu cywilnego Królestwa Polskiego z roku 1825 roku. Następnie w 1836 roku weszło w życie prawo o małżeństwie utrzymujące religijny charakter tej instytucji. Zaręczyny zostały regulowane w ust. 239-243.

$\mathrm{Na}$ obszarze zaboru austriackiego doszło w 1783 roku, w czasie panowania Józefa II, do całkowitego zniesienia prawa kościelnego w sprawach małżeńskich i poddania go prawu i sądownictwu świeckiemu'. Dopiero konkordat z 1855 roku przywrócił prawa Kościoła. W okresie józefińskim zniesiono także na pewien czas instytucję zaręczyn. Kwestie prawa małżeńskiego znalazły się w kodeksie cywilnym z 1811 roku $^{10}$. Kodeks austriacki regulował zaręczyny w $\$ 45$.

W zaborze pruskim obowiązywał kodeks cywilny z 1896 roku $^{11}$. Ponownie uregulowano w nim instytucję zaręczyn ( $\$ 1297-1302$ B GB), gdyż poprzednio obowiązujące ustawy cywilne nie zawierały odpowiednich postanowień.

Na terenach zabużańskich wcielonych do Cesarstwa Rosyjskiego obowiązywał Zwód Praw, który wszedł w życie w 1835 roku. Znajdujące się na początku tego kodeksu przepisy dotyczące małżeństwa nie zawierały regulacji dotyczącej

6 Por. H. Konic, Prawo..., dz. cyt., s. 56.

7 Por. H. Lutostański, Zaręczyny w prawie małżeńskim z 1836 r., „Gazeta Sądowa Warszawska” $1907 \mathrm{nr}$ 4, s. 48.

8 Por. H. Konic, Prawo..., op. cit., s. 22.

9 Por. S. Pelczar, Prawo małżeńskie katolickie, Kraków 1885, s. 25.

${ }_{10}$ Zob. Allgemeines bürgerliches Gesetzbuch [dalej: ABGB], Patent cesarski z 1 czerwca $1811 \mathrm{r}$. 1. 946 Zbioru ustaw sądowych za lata 1780-1848.

${ }_{11}$ Zob. Bürgerliches Gesetzbuch [dalej: BGB], Reichsgesetzblatt 1896, S. 195, Nr. 21. 
zaręczyn. Ze względu na wyrażoną w ust. 12 zasadę ochrony swobodnej woli zawierających związek małżeński, orzecznictwo przyjmowało, że obietnica zawarcia małżeństwa nie stanowi zobowiązania w sensie cywilnym, którego niewykonanie pociągałoby obowiązek wynagrodzenia skód i strat. Dlatego cofnięcie przez narzeczoną danego słowa, nawet gdy nie powiadomiła ona o tym narzeczonego, nie dawało mu podstawy do żądania zwrotu kosztów poniesionych na przygotowanie do ślubu ${ }^{12}$.

Ponieważ projekt prawa małżeńskiego przygotowany przez Komisję Kodyfikacyjną w latach 20. Xx wieku nie stał się obowiązującym prawem, porządki dzielnicowe przetrwały drugą wojnę światową. Dopiero dekret z 1945 roku, obowiązujący od 1 stycznia 1946 roku, ujednolicił stan prawny na terenie państwa polskiego. Został on w 1950 roku zastąpiony kodeksem rodzinnym, w którym instytucja zaręczyn już się nie znalazła.

\subsection{Zaręczyny w ustawodawstwach państw zaborczych}

Charakter prawny zaręczyn jako instytucji prawa zobowiązań (umowy, umowy przedwstępnej) czy też prawa familijnego był przedmiotem sporów ${ }^{13}$.

Co do zasady zaręczyny nie musiały poprzedzać małżeństwa. Jedynie na podstawie prawa o małżeństwie z 1836 roku istniał przed ogłoszeniem zapowiedzi obowiązek - spoczywający na proboszczu - upewnienia się co do wzajemnego zezwolenia stron na małżeństwo (art. 41). To istnienie wzajemnego zezwolenia wywodzono z wcześniejszych zaręczyn.

Przepisy prawne dotyczące zaręczyn koncentrowały się na kilku podstawowych kwestiach:

- formie i przesłankach zawarcia zaręczyn,

- wyłączeniu obowiązku zawarcia małżeństwa przez narzeczonych,

- usprawiedliwionych przyczynach zerwania zaręczyn i odpowiedzialności za zerwanie zaręczyn: odpowiedzialności odszkodowawczej za poniesione straty, zwrotu podarunków zaręczynowych, zadośćuczynienia dla kobiety,

- szczególnych skutkach zaręczyn,

- przedawnieniu roszczeń.

Przepisy dotyczące formy zawarcia zaręczyn były bardzo liberalne. Brak wymagań co do formy to charakterystyczna cecha porządków prawnych obowiązujących na ziemiach polskich.

${ }_{12}$ Por. Z. Rymowicz, W. Święcicki, Prawo cywilne ziem wschodnich. Tom x. Cz. 1 Zwodu Praw Rosyjskich. Tom 1, Warszawa 1933, s. 5.

${ }_{13}$ Obszerne omówienie teorii stosunku prawnego zaręczyn zostało przedstawione w: H. Lutostański, Zaręczyny w prawie małżeńskim z 1836 r., „Gazeta Sądowa Warszawska” 1907 nr 3, s. 34-35. 
$\mathrm{W}$ innych krajach kwestia ta była niekiedy regulowana odmiennie, np. we Włoszech oraz w Hiszpanii wymagano formy aktu notarialnego ${ }^{14}$.

Prawo austriackie nie wprowadzało obowiązku zachowania żadnej szczególnej formy zawarcia zaręczyn.

Podobnie było w prawie niemieckim. Zaręczyny podlegały ogólnym przepisom dotyczącym ważności czynności prawnych, co oznaczało, że czynności tej mogła dokonać osoba po przekroczeniu siódmego roku życia, za zezwoleniem przedstawiciela ustawowego ( $\$ 104 \mathrm{nn}$ в GB). Zawarcie zaręczyn przez osobę zaręczoną już z kimś innym uznawano za sprzeczne $\mathrm{z}$ dobrymi obyczajami, co powodowało nieważność czynności na podstawie $\$ 138 \mathrm{BGB}^{15}$.

Także w zaborze rosyjskim zaręczyny nie wymagały co do zasady szczególnej formy. Mogły być zawarte ustnie lub pisemnie, w akcie urzędowym lub prywatnym. Przepis ten został zapożyczony z prawa kanonicznego - dekretałów Grzegorza IX ${ }^{16}$. Zachowanie formy pisemnej lub obecność świadków były natomiast przesłankami powstania roszczeń odszkodowawczych. Prawo o małżeństwie z 1836 roku jako jedyny akt prawny spośród obowiązujących na ziemiach polskich wyraźnie stanowiło, że zaręczyny nie są ważne, jeżeli zostały zawarte przez osoby, między którymi istniały przeszkody do zawarcia małżeństwa (ust. 240). Zaręczyny można było zawrzeć tylko osobiście ${ }^{17}$.

W żadnym z obowiązujących porządków prawnych nie istniała możliwość przymuszenia narzeczonego do zawarcia małżeństwa na drodze sądowej.

W prawie niemieckim zasada ta została wyrażona w $\$ 1297$ BGB. Przepis ten mówił o braku skargi o zawarcie małżeństwa, co oznaczało, że zobowiązanie do zawarcia związku małżeńskiego było zobowiązaniem naturalnym ${ }^{18}$. Paragraf ten wprowadzał także zakaz zastrzegania kary umownej na wypadek niezawarcia małżeństwa.

Także w prawie austriackim zaręczyny nie powodowały ani obowiązku zawarcia małżeństwa ani spełnienia tego, co na wypadek odstąpienia od zaręczyn przyrzeczono ( $\$ 45$ A BGB). Orzecznictwo austriackie dopuszczało jednak

${ }^{14}$ Por. Prawo cywilne. Repertorium egzaminacyjne opracowane na podstawie wykładów uniwersyteckich prof. K. Lutostańskiego i H. Konica, t. 1, Warszawa 1931, s. 62.

${ }_{15}$ Por. Z. Lisowski, Kodeks cywilny obowiązujący na ziemiach zachodnich RP, Poznań 1933, s. 586.

${ }^{16}$ Por. H. Konic, Prawo..., dz. cyt., s. 57.

${ }_{17}$ Por. E. Muszalski, Prawo cywilne obowiązujące w b. Królestwie Kongresowym, Warszawa 1932, s. 113.

${ }_{18}$ Por. H. Lutostański, Zaręczyny w prawie małżeńskim z 1836 r., „Gazeta Sądowa Warszawska” 1907 nr 9, s. 125. 
możliwość przyrzeczenia po zerwaniu zaręczyn pewnego świadczenia w zamian za zwolnienie ze słowa ${ }^{19}$.

Rosyjskie prawo o małżeństwie z 1836 roku również nie wprowadziło obowiązku zawarcia małżeństwa w wyniku zaręczyn. Natomiast orzecznictwo rosyjskie jako jedyne dopuszczało możliwość zastrzeżenia kary umownej za niedotrzymanie obietnicy zawarcia małżeństwa ${ }^{20}$.

Brak możliwości dochodzenia obowiązku zawarcia małżeństwa na drodze sądowej nie oznaczał braku jakichkolwiek konsekwencji uchylenia się od małżeństwa. Mogły bowiem powstać roszczenia odszkodowawcze, uzależnione od istnienia albo braku istnienia uzasadnionej przyczyny zerwania.

$\mathrm{W}$ prawie niemieckim odstąpienie od zaręczyn bez ważnego powodu, jak również zawinione spowodowanie odstąpienia od zaręczyn przez drugą stronę rodziło odpowiedzialność odszkodowawczą wobec drugiego narzeczonego i jego rodziców, a także osób trzecich działających zamiast rodziców ( $\$ 1297$, 1298 в GB). Odpowiedzialność ta obejmowała poczynione wkłady i zaciągnięte zobowiązania. Ponadto drugiemu narzeczonemu należało także wynagrodzić szkodę wynikłą z innych zarządzeń dotyczących jego majątku lub sposobu zarobkowania. W grę wchodziły następujące rodzaje szkód:

1. wyprawa dla narzeczonej,

2. koszty urządzenia mieszkania ${ }^{22}$,

3. rezygnacja $\mathrm{z}$ wykonywanej pracy ${ }^{23}$.

Jako szkody nie traktowano natomiast odrzucenia lepszej partii ${ }^{24}$.

Za usprawiedliwione przyczyny zerwania zaręczyn orzecznictwo niemieckie uznawało brak wymaganej zgody rodziców na małżeństwo, błąd co do dziewictwa narzeczonej, błąd co do sytuacji majątkowej drugiej strony, kilkukrotne odraczanie małżeństwa bez przyczyny, chorobę, która zaistniała lub stała się wiadoma drugiej stronie po zaręczynach ${ }^{25}$. Już w okresie dwudziestolecia międzywojennego Sąd Najwyższy uznał, że niewłaściwe postępowanie narzeczonego przejawiające się w żądaniu pieniędzy po zaręczynach stanowi

19 Por. S. Wróblewski, Powszechny austriacki kodeks cywilny. Część pierwsza, Kraków 1914, s. 46; W. Jaworski, Kodeks cywilny austriacki, t. 1, Kraków 1905, s. 38.

${ }^{20}$ Por. Prawo cywilne obowiązujące na obszarze b. Kongresowego Królestwa Polskiego, red. J. J. Litauer, Warszawa 1929, s. 173.

${ }^{21}$ Por. Z. Lisowski, Kodeks..., dz. cyt., s. 587.

${ }^{22}$ Por. Z. Lisowski, Kodeks..., dz. cyt., s. 587.

${ }^{23}$ Por. Z. Lisowski, Kodeks..., dz. cyt., s. 587.

${ }^{24}$ Por. Z. Lisowski, Kodeks..., dz. cyt., s. 587.

${ }^{25}$ Por. Z. Lisowski, Kodeks..., dz. cyt., s. 587. 
usprawiedliwioną przyczynę zerwania zaręczyn przez narzeczoną, ponieważ może wywołać u niej uzasadnione przekonanie o jedynie materialnych pobudkach narzeczonego ${ }^{26}$.

Natomiast powołanie się na złą opinię kobiety nie stanowiło uzasadnionej przyczyny zarwania zaręczyn, jeżeli opinia ta była wcześniej drugiej stronie znana ${ }^{27}$.

Generalnie doktryna niemiecka przyjmowała, że za usprawiedliwione przyczyny zerwania zaręczyn należy traktować te same przyczyny, które usprawiedliwiały rozwód (art. $1565 \mathrm{BGB})^{28}$.

W kodeksie austriackim wynagrodzenia rzeczywistej szkody (tj. w granicach ujemnego interesu umownego) z tytułu niedotrzymanych zaręczyn mogła żądać tylko ta strona, po której nie było żadnej uzasadnionej przyczyny odstąpienia ( $\$ 46 \mathrm{ABGB}$ ). Warunkiem powstania roszczeń było istnienie ważnych zaręczyn. Jednak pomimo braku formalnych zaręczyn judykatura austriacka dopuściła możliwość przyznania wynagrodzenia za świadczone przez kilka lat usługi gospodarskie kobiecie, które to prace spełniała w domu mężczyzny w nadziei, że ten ją poślubi ${ }^{29}$.

Roszczenia z $\$ 46$ przysługiwały nie tylko narzeczonemu, lecz także np. ojcu narzeczonego, który poniósł szkodę $e^{30}$.

Sporna w orzecznictwie była kwestia, czy „słuszne przyczyny”, o których była mowa w $\$ 46$, muszą być zawinione - zgodnie z ogólnymi zasadami odpowiedzialności za szkodę, a więc czy prawo do odszkodowania przysługuje stronie, która odstąpiła z powodu np. choroby drugiej strony ${ }^{31}$. Doktryna, opierając się na analizie prac ustawodawczych, opowiadała się za traktowaniem jako uzasadnionej przyczyny także sytuacji niezawinionych ${ }^{32}$.

${ }^{26}$ Zob. Orz. SN z 21.09.1936 r., C III 1088/36, Zb. Orz. 1937, Zeszyt v, poz. 182.

${ }_{27}$ Zob. Wyrok sn z 1.05.1928 r., C. 63/28, „Czasopismo Adwokatów” 1928 z. 2, s. 7-9.

${ }_{28}$ Por. H. Lutostański, Zaręczyny w prawie małżeńskim z 1836 r., „Gazeta Sądowa Warszawska” $1907 \mathrm{nr}$ 15, s. 222.

${ }^{29}$ Por. S. Wróblewski, Powszechny austriacki kodeks cywilny. Część pierwsza, dz. cyt., s. 46.

${ }^{30}$ Por. S. Wróblewski, Powszechny austriacki kodeks cywilny. Część pierwsza, dz. cyt., s. 46. Odmiennie W. Jaworski, Prawo cywilne obowiązujące na ziemiach polskich, WarszawaKraków 1919, s. 40, który prawo to przyznaje tylko narzeczonym, bez względu na to, kto poniósł koszty.

${ }^{31}$ Por. S. Wróblewski, Powszechny austriacki kodeks cywilny. Część pierwsza, dz. cyt., s. 46; W. Dbałowski, W. Przeworski, Kodeks cywilny, Warszawa 1927, s. 59; W. Jaworski, Prawo..., dz. cyt., s. 40.

${ }^{32}$ Por. E. Till, Prawo prywatne austriackie, t. 5: Wykład prawa familijnego, Lwów 1902, s. 12-13. 
Przyczyna usprawiedliwiająca odstąpienie od zaręczyn musiała powstać po zawarciu zaręczyn ${ }^{33}$. Jako nieuzasadnione przyczyny odstąpienia od zaręczyn judykatura austriacka potraktowała podanie narzeczonemu przez rodzinę narzeczonej jej młodszego niż w rzeczywistości wieku ${ }^{34}$. Przyjmowano, że generalnie chodzi o przyczyny, które udaremniałyby cele małżeństwa lub podważały zaufanie do drugiej strony ${ }^{35}$.

W orzecznictwie austriackim za szkody podlegające rekompensacie uznano koszty wyprawy oraz jej wysłania, koszty zapowiedzi oraz urządzenia przyjęcia weselnego ${ }^{36}$.

$\mathrm{Na}$ terenie Królestwa Polskiego przesłanką powstania roszczeń odszkodowawczych (w zakresie rzeczywistych strat) było zachowanie formy pisemnej zaręczyn lub obecność świadków. Odpowiedzialność odszkodowawcza obciążała stronę, która bez słusznych przyczyn nie dotrzymała obietnicy zawarcia małżeństwa. Przepisy zawierały katalog uzasadnionych przyczyn (ust. 242), takich jak: ciężkie obelgi, rozwiązłe lub występne życie, nieokazywanie należnego uszanowania rodzicom strony oraz podstępne wyłudzenie danego słowa. Katalog ten nie miał charakteru wyczerpującego ${ }^{37}$. Słuszne przyczyny zerwania zaręczyn nie musiały być zawinione przez stronę ${ }^{38}$.

Roszczenia, według literalnego brzmienia ust. 241 prawa o małżeństwie $\mathrm{z} 1836$ roku, przysługiwały tylko narzeczonym, nie zaś rodzicom czy osobom trzecim $^{39}$. Te osoby, w szczególności rodzice niedoszłej panny młodej, mogły ewentualnie dochodzić odszkodowania na zasadach ogólnych ${ }^{40}$.

Jako przykłady szkód podlegających rekompensacie podawano wydatki na przygotowanie obrzędów ślubnych, koszty wyprawy oraz wydatki na urządzenie przyszłego domu ${ }^{41}$.

Oprócz roszczeń odszkodowawczych z tytułu strat majątkowych przepisy dawały niekiedy możliwość zrekompensowania narzeczonej pewnych szkód

33 Por. S. Wróblewski, Powszechny austriacki kodeks cywilny. Część pierwsza, dz. cyt., s. 46.

${ }^{34}$ Por. S. Wróblewski, Powszechny austriacki kodeks cywilny. Część pierwsza, dz. cyt., s. 46.

35 Por. E. Till, Prawo..., dz. cyt., s. 14.

${ }^{36}$ Por. S. Wróblewski, Powszechny austriacki kodeks cywilny. Część pierwsza, dz. cyt., s. 46; W. Dbałowski, W. Przeworski, Kodeks..., dz. cyt., s. 59.

37 Por. H. Konic, Prawo..., dz. cyt., s. 6o; Prawo..., red. J. J. Litauer, dz. cyt., s. 174.

${ }^{38}$ Por. H. Konic, Prawo..., dz. cyt., s. 6o.

39 Por. Prawo cywilne. Repertorium egzaminacyjne opracowane na podstawie wykładów uniwersyteckich prof. K. Lutostańskiego, t. 1, Warszawa 1931, s. 64.

${ }^{40}$ Por. H. Konic, Prawo..., dz. cyt., s. 60.

${ }^{41}$ Por. H. Konic, Prawo..., dz. cyt., s. 6o. 
o charakterze moralnym, względnie wprowadzały obowiązek alimentacji urodzonego dziecka.

W prawie niemieckim przewidziano możliwość żądania przez kobietę („nieposzkalowaną narzeczoną”) zadośćuczynienia za cielesne obcowanie $(\$ 1300$ BGB).

W prawie austriackim roszczenie takie nie było przewidziane wprost w przepisach o zaręczynach. Istniał natomiast przepis $\$ 1328$ A BGB, który przewidywał odpowiedzialność odszkodowawczą za uwiedzenie kobiety „przez działanie karygodne albo w ogóle przez podstęp”, za który uznawano także obietnicę małżeństwa ${ }^{42}$. Pierwotnie odpowiedzialność istniała tylko $\mathrm{w}$ przypadku urodzenia dziecka i obejmowała koszty porodu i połogu. Jednak tzw. III nowela do kodeksu austriackiego z 1916 roku wprowadziła odpowiedzialność niezależną od urodzenia dziecka.

Prawo o małżeństwie z 1836 roku stanowiło, że jeżeli kobieta zaszła w ciążę z narzeczonym, a nie doszło do zawarcia małżeństwa, ojciec dziecka był zobowiązany do alimentów na rzecz dziecka, a także na rzecz matki, jeśli nie miała własnego dostatecznego majątku (ust. 243).

Przepisy zaborcze poruszały także kwestię zwrotu podarunków przekazanych w związku z zaręczynami. Specjalne regulacje umiejscawiano w przepisach o zaręczynach albo wywodzono zasady zwrotu z norm ogólnych dotyczących bezpodstawnego wzbogacenia lub darowizn.

Według $\$ 1301$ в GB, w razie niedojścia do zawarcia małżeństwa, narzeczeni mogli żądać od siebie, na zasadach niesłusznego wzbogacenia, zwrotu podarunków danych na znak zawarcia zaręczyn. Roszczenie to było niezależne od przyczyn zerwania zaręczyn lub winy którejkolwiek ze stron ${ }^{43}$. Śmierć jednego z narzeczonych powodowała co do zasady upadek prawa do żądania zwrotu podarunków ( $\$ 1300$ BGB).

Roszczenie takie nie było przewidziane wprost w prawie austriackim. Orzecznictwo przyjęło, że bezpodstawne odstąpienie od zaręczyn pozbawiało możliwości żądania zwrotu rzeczy darowanych ${ }^{44}$. W odróżnieniu zatem od prawa niemieckiego możliwość żądania zwrotu podarków uzależniona

${ }^{42}$ Por. S. Wróblewski, Powszechny austriacki kodeks cywilny. Część druga, Kraków 1918, s. 1170; J. Roth, Forma..., dz. cyt., s. 26.

${ }^{43}$ Por. S. Tylbor, Małżeńskie prawo, w: Encyklopedia prawa prywatnego, t. 3, red. F. Zoll, J. Wasilkowski, Warszawa, b.m.r.w., s. 737.

${ }^{44}$ Por. W. Dbałowski, W. Przeworski, Kodeks..., dz. cyt., s. 59. 
była od braku winy ${ }^{45}$. Judykatura austriacka przyjęła także, że prawo żądania zwrotu nie było dziedziczne ${ }^{46}$.

Na terenie Królestwa Kongresowego przepisy prawa o małżeństwie nie regulowały wprost kwestii zwrotu podarków zaręczynowych. Orzecznictwo przyjęło, że w takiej sytuacji należało stosować art. $1088 \mathrm{kN}$, zgodnie z którym wszelkie darowizny uczynione przez wzgląd na małżeństwo upadały, jeśli małżeństwo nie doszło do skutku ${ }^{47}$. Doktryna wskazywała ponadto na art. $1142 \mathrm{KN}$ mówiący o tym, że każde zobowiązanie czynienia lub nieczynienia w razie niewykonania ze strony dłużnika zamieniało się w zobowiązanie wynagrodzenia szkód i strat ${ }^{48}$.

Przepisy zaborcze wprowadzały ponadto szczególne uregulowania, które odnosiły się do skutków prawnych zaręczyn.

$\mathrm{Na}$ gruncie prawa niemieckiego zawarcie zaręczyn umożliwiało zawarcie umowy dziedziczenia ( $\$ 2275$ BGB), tj. umowy zawieranej pomiędzy spadkodawcą a spadkobiercami lub zapisobiercami. Umowa taka, w odróżnieniu od testamentu, miała charakter wiążący i nie mogła być swobodnie odwołana przez spadkodawcę. Uprzywilejowanie małżonka i narzeczonego polegało na tym, że mogli oni zawrzeć umowę dziedziczenia pomimo posiadania tylko ograniczonej zdolności do czynności prawnych.

Także w prawie austriackim możliwość zawierania kontraktów dziedziczenia pomiędzy małżonkami na podstawie $\$ 1249$ ABGB rozciągnięto na narzeczonych, o ile doszło do zawarcia małżeństwa ${ }^{49}$. W odróżnieniu natomiast od prawa niemieckiego ( $\$ 2265$ BGB), na gruncie prawa austriackiego istniała możliwość zawierania przez narzeczonych tzw. testamentów wzajemnych $(\$ 1248 \mathrm{ABGB})^{50}$.

Według prawa $\mathrm{z} 1836$ roku zawarcie zaręczyn skutkowało powstaniem przeszkody małżeńskiej i jeżeli zaręczyny zostały zawarte uroczyście, przy kapłanie i świadkach, wówczas strona zaręczona nie mogła zawrzeć małżeństwa z krewnym pierwszego stopnia kanonicznego (ust. 37).

45 Por. W. Jaworski, Prawo..., dz. cyt., s. 42.

${ }^{46}$ Por. W. Jaworski, Prawo..., dz. cyt., s. 42.

47 Por. Prawo..., red. J. J. Litauer, dz. cyt., s. 456.

${ }^{48}$ Por. H. Konic, Prawo..., dz. cyt., s. 62.

49 Por. W. Jaworski, Prawo..., dz. cyt., s. 39; W. Dbałowski, W. Przeworski, Kodeks..., dz. cyt., S. 1251.

${ }^{50}$ Por. W. Jaworski, Prawo..., dz. cyt., s. 39. 
Spośród kodeksów zaborczych jedynie w prawie niemieckim wprowadzono szczególny przepis dotyczący przedawnienia roszczeń wynikających z narzeczeństwa. Przedawniały się one z upływem dwóch lat (\$1302 BGB).

\section{Zaręczyny w prawie polskim po 1918 roku}

Jednym z owoców prac utworzonej w 1919 roku Komisji Kodyfikacyjnej był projekt prawa małżeńskiego, uchwalony 28 maja 1929 roku $^{51}$. Według projektu zaręczyny nie wymagały szczególnej formy. Konieczne było jedynie, aby przyrzeczenie małżeństwa było wyraźne. Za wzorem prawa z 1836 roku postanowiono, że zaręczać mogły się tylko osoby zdolne do zawarcia małżeństwa.

Nie można było wnieść skargi o zawarcie małżeństwa. Niedopuszczalne było także zastrzeżenie kary umownej ani jakiejkolwiek innej korzyści na wypadek odstąpienia od zaręczyn (art. 2). Takie brzmienie przepisu było najbardziej zbliżone do $\$ 45$ ABGB.

Projekt wprowadzał bardzo szeroką odpowiedzialność za odstąpienie od zaręczyn bez słusznego powodu (art. 3), przy czym brzmienie przepisów wskazywało, że powody te nie musiały być zawinione. Po pierwsze, istniała odpowiedzialność odszkodowawcza wobec narzeczonego, jego rodziców lub osób trzecich działających zamiast rodziców, za straty spowodowane uzasadnionymi przygotowaniami do małżeństwa. Po drugie, wprowadzono zadośćuczynienie za szkodę moralną. Taki zapis nie był znany ustawom obowiązującym w państwach zaborczych.

Z art. 4 projektu wynikał obowiązek zwrotu podarków zaręczynowych. Roszczenie o zwrot nie przysługiwało stronie winnej odstąpienia, co zbliżało projekt do zasad uznawanych w orzecznictwie austriackim. Projekt nie regulował natomiast wprost kwestii, czy prawo żądania zwrotu podarków przysługuje także temu, kto dał drugiej stronie słuszny powód do odstąpienia, zwłaszcza jeśli powód ten był niezawiniony (np. zapadnięcie na ciężką chorobę) ${ }^{52}$.

Projekt wprowadzał krótki, jednoroczny termin przedawnienia roszczeń majątkowych wynikłych z ustania lub zerwania zaręczyn (art. 5).

Nowością, nie tylko w polskim systemie prawnym, był przepis art. 6 projektu. Przyznawał on narzeczonej, która zaszła w ciążę, prawo żądania podziału i przyznania jej majątku narzeczonego na równi z żoną rozłączoną (tzn. jak

${ }^{51}$ Zob. Projekt prawa małżeńskiego uchwalony przez Komisję Kodyfikacyjną w dniu 29 maja 1929 r., Komisja Kodyfikacyjna. Podsekcja I Prawa Cywilnego, t. 1, z. 1, Warszawa 1931.

${ }_{52}$ Por. S. Tylbor, Uwagi o projekcie polskiego prawa małżeńskiego, Warszawa 1933, s. 5. 
przy separacji) z winy męża, jeżeli narzeczony zmarł lub bez słusznych powodów odstąpił od zaręczyn albo dał powód do odstąpienia. Wprowadzenie takiego zapisu uzasadniono „istotą stosunku narzeczeńskiego, który powstaje przez przyrzeczenie małżeństwa [...], jeżeli narzeczona zajdzie z narzeczonym w ciążę - to powinni być oboje, co do wzajemnych obowiązków stąd wynikłych, traktowani jako związani przyrzeczeniem małżeńskim”s3.

Projekt Komisji Kodyfikacyjnej nie stał się jednak obowiązującym prawem ze względu na opór ze strony Kościoła i środowisko katolickich. Krytyka ta dotyczyła również zaręczyn, gdyż uważano, że zrównanie narzeczonej z żoną w zakresie prawa do żądania podziału majątku, „mogłoby być zachętą dla wielu kobiet do lekkomyślnego obcowania z narzeczonym"54. Nadal obowiązywały zatem dawne ustawodawstwa zaborcze i dopiero po drugiej wojnie światowej nastąpiła unifikacja prawa, którą wprowadzał dekret z 25 września 1945 roku, obowiązujący od 1 stycznia 1946 roku5 . Dekret był częściowo oparty na projekcie z 1929 roku. Choć kwestionowano w tamtym czasie potrzebę regulacji prawnej, to przepisy dotyczące zaręczyn znalazły się ostatecznie w dekrecie (art. 1-4). Jednym z powodów był fakt, że po drugiej wojnie światowej instytucja zaręczyn nadal funkcjonowała w 12 krajach europejskich (Bułgaria, Włochy, Szwajcaria, Holandia, Dania, Szwecja, Niemcy, Finlandia, Anglia, Grecja, Jugosławia, Czechosłowacja i Węgry) ${ }^{56}$.

Zaręczyny traktowano jako umowę przedwstępną w stosunku do małżeństwa, analogiczną do umowy przedwstępnej z art. 62 kodeksu zobowiązań Z 1934 roku, do której jednak nie można było stosować przepisów kodeksu zobowiązań ${ }^{57}$.

W odróżnieniu od prawa małżeńskiego z 1836 roku przepisy dekretu nie ustanawiały żadnych przesłanek ważności zaręczyn. Rodziło to wątpliwości co do możliwości zawarcia zaręczyn przez osoby niepełnoletnie. Z jednej

53 Zob. Zasady projektu prawa małżeńskiego uchwalonego przez Komisję Kodyfikacyjna w dniu 29 maja 1929 r., opracował główny referent projektu prof. K. Lutostański, Komisja Kodyfikacyjna. Podsekcja I Prawa cywilnego, t. 1, z. 3, Warszawa 1931, s. 62.

${ }^{54}$ Por. H. Insadowski, Zaręczyny, w: Rozbiór krytyczny prawa matżeńskiego uchwalony przez K.K., red. J. Wiślicki, Lublin 1932, s. 53; a także: J. Jaglarz, Problem kodyfikacji prawa małżeńskiego w Polsce, Poznań 1934, s. 76; L. Domański, O małżeństwie, Warszawa 1932, s. 129; odmiennie: O. Halecki, w: Ankieta w sprawie projektu prawa małżeńskiego uchwalonego przez K.K., Lublin 1932, s. 33 .

55 Dekret z dnia 25 września 1945 r. Prawo małżeńskie (Dz. U. z 1945 r. Nr 48, poz. 270).

56 Por. S. Szer, Zaręczyny, „Demokratyczny Przegląd Prawniczy” 1946 nr 1, s. 14.

57 Por. J. Witecki, Prawo małżeńskie. Komentarz, Łódź 1946, s. 6. 
strony wskazywano na brak przeszkód do zaręczania się osób niepełnoletnich $^{58}$. Z drugiej strony, z przewidzianej w art. $6 \$ 1$ prawa małżeńskiego zasady, że małżeństwo mogli zawrzeć mężczyzna i kobieta, którzy ukończyli osiemnasty rok życia, wyprowadzano pogląd, że niedopuszczalne były zaręczyny osób niepełnoletnich ${ }^{59}$. Z kolei wobec braku ograniczeń w zawieraniu związku małżeńskiego przez osoby pełnoletnie, ograniczone w zdolności do czynności prawnych uznawano, że mogły się one także zaręczyćco.

Zaręczyny nie wymagały jakiejkolwiek formy. Mogły być także zawarte przez pełnomocnika.

Zaręczenie się z dwiema osobami uznawano za nieważne (co do drugich zaręczyn) lub nakazywano traktować jako odstąpienie od poprzednich zaręczyn ${ }^{61}$.

Zgodnie $\mathrm{z}$ art. 1 prawa małżeńskiego niedopuszczalne było wystąpienie z powództwem o zawarcie małżeństwa. Niedopuszczalne było także zastrzeżenie kary umownej na wypadek odstąpienia od zaręczyn (art. $1 \$ 2$ prawa małżeńskiego).

Odstąpienie od zaręczyn bez słusznych powodów lub danie drugiemu słusznego powodu do odstąpienia skutkowało odpowiedzialnością - za straty spowodowane uzasadnionymi przygotowaniami do zawarcia małżeństwa - wobec narzeczonego, jego rodziców lub osób działających zamiast rodziców.

Za słuszne powody uznano takie, które, gdyby ujawniły się po zawarciu małżeństwa, uzasadniałyby orzeczenie rozwodu ${ }^{62}$. Mogły to być zachowania, które miały miejsce przed zaręczynami, jeśli nie były znane drugiej stronie. Za słuszną przyczynę uznano sytuację, gdy strona przy bliższym poznaniu wykazała takie cechy charakteru lub takie zachowania, które wykluczałyby zgodność pożycia ${ }^{63}$. Za słuszną przyczynę nie należało natomiast uznawać błędu co stanu majątkowego drugiej strony, w szczególności nienastąpienie oczekiwanej zmiany stanu majątkowego ${ }^{64}$. Niekoniecznie musiały to być przyczyny zawinione, np. nieprzemijająca choroba narzeczonego. Natomiast danie słusznego powodu do odstąpienia powinno było być zawinione ${ }^{65}$.

\footnotetext{
${ }^{8}$ Por. S. Szer, Zaręczyny, dz. cyt., s. 15.

59 Por. J. Witecki, Prawo..., dz. cyt., s. 7.

${ }^{60}$ Por. J. Witecki, Prawo..., dz. cyt., s. 7.

${ }^{61}$ Por. J. Witecki, Prawo..., dz. cyt., s. 9.

${ }^{62}$ Por. J. Witecki, Prawo..., dz. cyt., s. 11.

${ }_{63}$ Por. S. Szer, Zaręczyny, dz. cyt., s. 16.

${ }^{64}$ Por. J. Witecki, Prawo..., dz. cyt., s. 12.

${ }^{65}$ Por. J. Witecki, Prawo..., dz. cyt., s. 12.
} 
Odszkodowanie przysługujące na podstawie art. 2 obejmowało uzasadnione przygotowania do zawarcia małżeństwa. Odszkodowanie przysługiwało tylko za straty, a więc w granicach ujemnego interesu ${ }^{66}$. Jako przykłady strat uznawano np. wyprawę i koszty urządzenia mieszkania ${ }^{67}$.

W razie niedojścia małżeństwa do skutku należał się zwrot podarków zaręczynowych. Z żądaniem tym nie mogła wystąpić strona winna odstąpienia od zaręczyn bez słusznego powodu (art. 3 dekretu). Zmodyfikowano tu zatem przepis prawa niemieckiego, na podstawie którego zwrot należał się niezależnie do słuszności istnienia uzasadnionych przyczyn do odstąpienia. Natomiast w odróżnieniu od kodeksu niemieckiego i projektu Komisji Kodyfikacyjnej roszczenie o zwrot podarków przysługiwało także innym osobom poza narzeczonymi.

W dekrecie z 1945 roku nie przewidziano roszczenia o zadośćuczynienie. Jednocześnie jednak w dekrecie z 22 stycznia 1946 roku - Prawo rodzinne, regulującym m.in. kwestię sytuacji prawnej dzieci pozamałżeńskich, istniał art. 54 $\$ 3$, który w przypadku urodzenia się dziecka wprowadzał możliwość żądania przez niedoszłą mężatkę zadośćuczynienia za krzywdę moralną. Przepis ten został pominięty w kodeksie rodzinnym z 1950 roku. Jednak przez pewien czas praktyka sądowa akceptowała możliwość zasądzania w takich przypadkach zadośćuczynienia na podstawie art. $165 \$ 2$ kodeksu zobowiązań, który przewidywał prawo do zadośćuczynienia za skłonienie podstępem do poddania się czynowi nierządnemu ${ }^{68}$. Oceniając spory o zadośćuczynienie za utraconą cześć, Sąd Najwyższy uznał także, że należy stosować przepisy z chwili żądania zadośćuczynienia, a nie zawarcia zaręczyn, co było niekorzystne dla mieszkańców byłego zaboru pruskiego ${ }^{69}$.

Roszczenia o naprawienie strat i zwrot podarków przedawniały się z upływem roku od ustania lub zerwania zaręczyn (art. 4). Roszczenia narzeczonego (a nie innych osób) przechodziły na spadkobierców, jeżeli powództwo zostało wytoczone za życia narzeczonego.

Instytucja zaręczyn została pominięta w kodeksie rodzinnym z 27 czerwca 1950 roku, który wszedł w życie 1 października $1950 \mathrm{roku}^{70}$. Nie spowodowało to całkowitego wyeliminowania problematyki zaręczyn $\mathrm{z}$ obrotu prawnego.

${ }^{66}$ Por. J. Witecki, Prawo..., dz. cyt., s. 13.

${ }^{67}$ Por. S. Szer, Zaręczyny, dz. cyt., s. 16.

${ }^{68}$ Por. K. Lipiński, Odszkodowanie za niedotrzymanie obietnicy małżeństwa, „Nowe Prawo” $1954 \mathrm{nr} 7-8$, s. 153.

${ }^{69}$ Zob. Orz. sN z 30.09.1948 r., C 518/48, „Nowe Prawo” 1948 nr 12, s. 130-131.

70 Ustawa z dnia 27 czerwca 1950 r. Kodeks rodzinny (Dz. U. z 1950 r., Nr 34, poz. 308). 
Już bowiem po wejściu w życie kodeksu rodzinnego z 1950 roku Sąd Najwyższy uznał, że bezpodstawne niestawienie się na ślub pomimo zawarcia zaręczyn uzasadnia żądanie zwrotu wydatków poniesionych na zorganizowanie przyjęcia weselnego na podstawie ogólnych przepisów o naprawieniu szkody wyrządzonej z własnej winy ${ }^{71}$.

\section{Zaręczyny w prawie kanonicznym}

Kiedy zaręczyny stały się przedmiotem zainteresowania prawa kanonicznego, szerzył się zwyczaj błogosławienia narzeczonych, czego konsekwencją był wzrost roli zaręczyn prowadzący do zrównania ich pod wieloma względami z małżeństwem, szczególnie na wschodzie Cesarstwa Rzymskiego. Nieuzasadnione zerwanie zaręczyn było ciężkim przestępstwem i skutkowało pozbawieniem możliwości przyjmowania Komunii św. przez okres 3 lat $^{72}$. Zawarcie małżeństwa z cudzą narzeczoną było karane jak cudzołóstwo. Narzeczeństwo było przeszkodą do zawarcia małżeństwa, a w razie śmierci narzeczonego małżeństwo zawarte następnie przez drugiego narzeczonego było traktowane jako drugie ${ }^{73}$.

Natomiast na zachodzie Europy zaręczyny nie osiągnęły aż takiego znaczenia, choć np. jeszcze przed soborem trydenckim skonsumowanie zaręczyn powodowało powstanie małżeństwa. Zasada ta formalnie została zniesiona dopiero $\mathrm{w} 1892 \mathrm{roku}^{74}$.

Prawo kanoniczne nie znało żadnej obowiązkowej formy zaręczyn. Zaręczyny mogły dokonać się nawet potajemnie. Zgoda na zaręczyny mogła być wyrażona także $\mathrm{w}$ formie konkludentnej, np. zgody dziewczyny na utratę panieństwa ${ }^{75}$. Początkowo zaręczyny mogły zostać zawarte za pośrednictwem rodziców także przed osiągnięciem przez narzeczonych dojrzałości, o ile po osiągnięciu dojrzałości narzeczeni nie odstąpili od zaręczyn w ciągu trzech dni ${ }^{76}$.

Zmienne było stanowisko Kościoła co do obecności kapłana przy zaręczynach. Na synodzie wrocławskim w 1248 roku uchwalono, że zaręczyny powinny odbywać się w obecności księdza i trzech świadków. W 1279 roku

\footnotetext{
${ }^{71}$ Zob. Orz. SN z 15.07.1953 r., II C 687/53, „Nowe Prawo” 1954 nr 6, s. 1098-1099.

72 Por. S. Biskupski, Prawo..., dz. cyt., s. 78-79.

73 Por. W. Abraham, Forma zawarcia zaręczyn i małżeństwa, Lwów 1909, s. 4.

74 Por. J. Pelczar, Prawo..., dz. cyt., s. 6o; S. Biskupski, Prawo..., dz. cyt., s. 81.

75 Por. J. Pelczar, Prawo..., dz. cyt., s. 66.

${ }^{76}$ Por. J. Pelczar, Prawo..., dz. cyt., s. 69; W. Abraham, Forma..., dz. cyt., s. 8.
} 
zakazano z kolei obecności kapłana, aby nie dochodziło do zrównania zaręczyn $\mathrm{z}$ małżeństwem. Generalnie jednak istniał zwyczaj obecności księdza przy zaręczynach, do czego nawiązywały uchwały synodów polskich z XVIII wie$\mathrm{ku}^{77}$. Powodem tych wahań był fakt, że pierwotnie łagodniejsze były wymogi co do formy zawarcia małżeństwa. W tej sytuacji dochodziło do zacierania się granic pomiędzy zaręczynami a małżeństwem i np. rozpoczynania wspólnego pożycia już po zaręczynach ${ }^{78}$.

Prawo kanoniczne nie dopuszczało możliwości zastrzeżenia kary umownej na wypadek niedotrzymania umowy zaręczynowej. Natomiast możliwe było, w ślad za prawem rzymskim, danie zadatku, który przepadał w razie zerwania zaręczyn $^{79}$.

Prawo kanoniczne przewidywało możliwość skargi o zawarcie małżeństwa na podstawie zaręczyn ${ }^{80}$. Jednak sądownictwo kościelne jeszcze przed soborem trydenckim zaczęło bardzo ostrożnie podchodzić do kwestii nakazywania zawarcia małżeństwa. Początkowo stosowano cenzury kościelne celem przymuszenia. Potem zaniechano nawet tej praktyki, ograniczając się do zasądzania odszkodowania ${ }^{81}$.

Kompleksowa regulacja zaręczyn w prawie kanonicznym została przeprowadzona dekretem Ne temere $\mathrm{z} 2$ sierpnia 1907 roku $^{82}$.

Według nowych przepisów ważność zaręczyn zależała od zachowania formy pisemnej. Dokument powinien być podpisany przez strony oraz albo proboszcza lub ordynariusza miejscowego, albo przynajmniej dwóch świadków. Jeżeli którykolwiek z narzeczonych nie umiał pisać, potrzebna była obecność jeszcze jednego dodatkowego świadka. Umieszczenie daty sporządzenia umowy zaręczynowej było warunkiem jej ważności ${ }^{83}$. Natomiast przepisy dekretu nie wskazywały, kto mógł sporządzić umowę zaręczynową. Wykluczono możliwość

77 Por. S. Dąbkowski, Polskie prawo..., dz. cyt., s. 345-347.

78 Por. J. Roth, Forma zaręczyn i małżeństwa, Kraków 1908, s. 6-7.

79 Por. H. Lutostański, Zaręczyny w prawie małżeńskim z 1836 r., „Gazeta Sądowa Warszawska” 1907 nr 8, s. 112.

${ }^{80}$ Por. W. Abraham, Forma..., dz. cyt., s. 9.

${ }^{81}$ Por. S. Biskupski, Prawo..., dz. cyt., s. 81; E. Rittner, Prawo kościelne katolickie, t. 2, Lwów 1913, s. 264.

${ }^{82}$ Por. W. Abraham, Forma..., dz. cyt., s. 54; Prawo małżeńskie kościelne według wykładów prof. dra Ulanowskiego, Kraków 1913, s. 91n; J. Pycia, Prawo kanoniczne matżeńskie, Kielce 1922, s. 12n; J. Roth, Forma..., dz. cyt., s. 10-19.

${ }^{83}$ Por. W. Szmyd, Praktyczny podręcznik prawa małżeńskiego, Kraków 1929, s. 119. 
wyrażenia zgody na zawarcie zaręczyn w sposób konkludentny. Żadna szczególna forma nie była natomiast wymagana dla rozwiązania zaręczyn.

Podobnie jak poprzednio, za niedopuszczalne uznano zastrzeżenie kary umownej za zerwanie zaręczyn. Możliwe natomiast było danie zadatku, który przepadał w razie zerwania zaręczyn. Choć dekret wyraźnie o tym nie mówił, przyjmowano, jak dawniej, że istnieje możliwość zawarcia zaręczyn przez pełnomocnika $^{84}$. Nie było już możliwości zawierania zaręczyn przez dzieci poniżej siedmiu lat.

Skutkiem ważnych zaręczyn były:

- powstanie obowiązku wzajemnej wierności,

- powstanie obowiązku zawarcia małżeństwa, który mógł być dochodzony na drodze sądowej. Mogły być także stosowane kary kościelne w celu przymuszenia do wykonania takiego wyroku. Jednak w razie niewykonania wyroku pomimo zastosowania cenzur powstawała tylko odpowiedzialność odszkodowawcza, przy czym warunkiem jej powstania była zgoda stron co do wysokości odszkodowania. Gdy jej nie było, odszkodowania można było dochodzić przed sądem świeckim. Odpowiedzialność odszkodowawcza na gruncie prawa kanonicznego była przy tym szeroka i obejmowała pełne odszkodowanie, a nie tylko poniesione wydatki, jeżeli narzeczony uwiódł narzeczoną, gdy straciła ona szansę na zamążpójście, gdy została zniesławiona,

- zakaz zawarcia kolejnych zaręczyn przez narzeczonego,

- powstanie przeszkody do zawarcia małżeństwa z inną osobą, od której mógł dyspensować tylko papież,

- powstanie przeszkody do zawarcia przez narzeczonego małżeństwa z krewnymi pierwszego stopnia drugiego narzeczonego. Była to przeszkoda przystojności publicznej, znana już wcześniej. Pierwotnie obejmowała ona wszystkich członków rodziny, z czasem ograniczona została do stopnia czwartego (przez Innocentego III), a potem pierwszego (przez Sobór Trydencki $^{85}$.

Zaręczyny ulegały rozwiązaniu:

- za zgodą stron,

- przez ziszczenie się warunku. Przy zaręczynach można było dodać warunek, który wprawdzie nie miał charakteru warunku zawieszającego albo

\footnotetext{
${ }^{84}$ Por. W. Abraham, Forma..., dz. cyt., s. 55.

${ }_{55}$ Por. Prawo małżeńskie kościelne $w$ porównaniu z prawem małżeńskim austriackiem według wykładów profesora dr Abrahama. Część I, Lwów 1911, s. 108.
} 
rozwiązującego, ale dawał prawo do zerwania zaręczyn, np. podjęcie starań o znalezienie pracy ${ }^{86}$,

- przez zawarcie małżeństwa przez jedno z narzeczonych,

- przez wstąpienie do klasztoru albo uzyskanie święceń wyższych,

- przez odstąpienie jednej ze stron od wiary,

- wskutek braku zgody rodziców, pod władzą których narzeczony pozostawał,

- przez niezachowanie wierności, udanie się do innego kraju, odwlekanie małżeństwa, istotną zmianę cech osobistych narzeczonych (choroba, naruszenie dobrych obyczajów),

- przez zaistnienie innych okoliczności natury fizycznej, moralnej lub majątkowej, które stanęłyby na przeszkodzie małżeństwu lub szczęśliwemu pożyciu, bez względu na to, czy zaistniały one dopiero po zaręczynach, czy też dopiero wtedy stały się wiadome.

Przepisy dekretu Ne temere z 1907 roku w zakresie uroczystej formy zawarcia zaręczyn zostały przejęte przez kodeks prawa kanonicznego z 1917 roku. Według kan. 1017 zaręczyny mogły mieć także charakter jednostronnego przyrzeczenia zawarcia małżeństwa. Jednostronna obietnica małżeństwa nie mogła jednak rodzić skutków na gruncie prawa cywilnego w zakresie prawa żądania odszkodowania ${ }^{87}$.

Z zaręczyn nie wynikała już przeszkoda małżeńska do zawarcia przez narzeczonego małżeństwa $\mathrm{z}$ krewnymi pierwszego stopnia drugiego narzeczonego (kan. 1078).

Istotną zmianą była rezygnacja z możliwości żądania zawarcia małżeństwa na drodze sądowej. Pozostawała jedynie odpowiedzialność odszkodowawcza. Niedopuszczalna była także skarga o stwierdzenie słusznej przyczyny zerwania zaręczyn $^{88}$.

Zmiana stanu prawnego nastąpiła w chwilą wejścia w życie kodeksu prawa kanonicznego z 1983 roku. Kanon 1062 zachował dwa rodzaje zaręczyn w postaci przyrzeczenia jednostronnego albo dwustronnego. Wykluczono możliwość wniesienia skargi o zawarcie małżeństwa. Zachowano natomiast skargę o wynagrodzenie szkód. W pozostałym zakresie zaręczyny pozostawiono do regulacji konferencjom episkopatu, z uwzględnieniem zwyczajów i prawa świeckiego. Realizując tę delegację, Konferencja Episkopatu Polski wydała 5 września 1986 roku instrukcję o przygotowaniu do zawarcia małżeństwa

\footnotetext{
${ }^{86}$ Por. W. Szmyd, Praktyczny podręcznik..., dz. cyt., s. 122.

${ }^{87}$ Por. W. Jaworski, Prawo..., dz. cyt., s. 42.

${ }^{88}$ Por. F. Bączkowicz, Prawo kanoniczne. Podręcznik dla duchowieństwa, t. 2, Opole 1858, s. 164.
} 
w Kościele Katolickim ${ }^{89}$. Traktując zaręczyny jako formę przygotowania do małżeństwa, pozwalającą narzeczonym lepiej się poznać, zalecono, aby zaręczyny odbywały się w gronie rodzinnym, na co najmniej 6 miesięcy przez zawarciem związku małżeńskiego. Znakiem zawarcia zaręczyn jest wymiana pierścionków zaręczynowych. Instrukcja dopuszcza możliwość powstania roszczeń o wynagrodzenie szkód, względnie wydatków, które powstały z racji zamierzonego małżeństwa.

\section{$* * *$}

Wyeliminowanie zaręczyn ze świeckiego porządku prawnego było rezultatem przemian społecznych, w tym zmniejszenia się roli materialnych pobudek do zawarcia małżeństwa oraz ochrony wolnej woli przy podejmowaniu decyzji o zawarciu małżeństwa. Nie oznacza to jednak całkowitego zaniku problemów prawnych, które mogą się pojawić w związku z zawarciem zaręczyn. We współczesnej literaturze wskazuje się bowiem, że skutki zaręczyn mogą być oceniane na podstawie odpowiednich przepisów prawa cywilnego dotyczących umów lub czynów niedozwolonych ${ }^{90}$. Wśród kanonistów dostrzega się natomiast przekonanie o potrzebie dalszego, choć oszczędnego uregulowania instytucji zaręczyn.

\section{ABSTRAKT}

W polskim systemie prawnym instytucja zaręczyn była regulowane niezależnie od siebie zarówno w prawie cywilnym, jak i kanonicznym. W prawie cywilnym były początkowo instytucją prawa zwyczajowego. W obcych porządkach prawnych obowiązujących na terytorium Polski w wieku xıx i pierwszej połowie wieku xx instytucja zaręczyn znalazła się w większości kodeksów. Regulacje te chroniły swobodę zawarcia małżeństwa, różne natomiast mogły być skutki majątkowe. Dopiero po drugiej wojnie światowej w Polsce udało się stworzyć własne prawo małżeńskie, które przez kilka lat obejmowało także zaręczyny. W prawie kanonicznym przez długi okres nie było jednolitych przepisów

${ }^{89}$ Instrukcja Konferencji Episkopatu Polski o przygotowaniu do zawarcia małżeństwa w Kościele Katolickim, „Akta Konferencji Episkopatu Polski” 1998 nr 1, s. 85-108.

${ }^{\circ}$ Por. K. Piasecki, w: Kodeks rodzinny i opiekuńczy z komentarzem, red. J. Pietrzykowski, Warszawa 1993, s. 97; roszczenia z tytułu zaręczyn omawia E. Kamarad, Charakter prawny zaręczyn w prawie materialnym i kolizyjnym, w: Hereditas Mercaturae. Ksiega Pamiątkowa dedykowana Profesorowi Stanisławowi Miklaszewskiemu, red. Z. Mach, P. Czubik, Kraków 2012. 
w odniesieniu do zaręczyn. Na początku xx wieku wprowadzono wymogi dotyczące prawnej formy zaręczyn. Przepisy te nie przetrwały jednak do czasów współczesnych.

\section{SŁoWA KLUCzowe}

zaręczyny, prawo małżeńskie

\section{ABstract}

\section{Legal Regulation of Engagement in Poland}

In Polish legal system the institution of engagement was regulated independently by both private and canon law. In the beginning, it was an institution of customary law. In foreign legal systems binding on the territory of Poland in the $19^{\text {th }}$ and the first half of $2 \mathrm{O}^{\text {th }}$ century, the institution of engagement could be found in most of civil codes. These regulations protected the freedom of entering into marriage, however, there could be differences in terms of property effects. It wasn't until the end of the Second World War that Poland was able to enact its own maritial law, in which the institution of engagement was regulated for a few years. In canon law, for a long time there had been no common rules concerning engagement. At the beginning of $2 \mathrm{O}^{\text {th }}$ century requirements concerning the legal form of engagement were imposed. However, these restrictions haven't survived until the present time.

\section{KEYWORDS}

engagement, maritial law

\section{BIBLIOGRAFIA}

Abraham W., Forma zawarcia zaręczyn i małżeństwa, Lwów 1909.

Allerhand M., Prawo małżeńskie obowiązujące na Spiszu i Orawie, Lwów 1926.

Ankieta w sprawie projektu prawa małżeńskiego uchwalonego przez K.K., Lublin 1932. Bączkowicz F., Prawo kanoniczne. Podręcznik dla duchowieństwa, t. 2, Opole 1858.

Biskupski S., Prawo małżeńskie Kościoła Rzymskokatolickiego, Warszawa 1956.

Dąbkowski S., Polskie prawo prywatne, t. 1, Warszawa 1910.

Dbałowski W., Przeworski W., Kodeks cywilny, Warszawa 1927.

Domański L., O małżeństwie, Warszawa 1932.

Gromnicki T., Forma zawierania zaręczyn i matżeństw, Kraków 1910.

Insadowski H., Zaręczyny, w: Rozbiór krytyczny prawa małżeńskiego uchwalony przez K.K., red. J. Wiślicki, Lublin 1932, s. 47-55.

Jaglarz J., Problem kodyfikacji prawa małżeńskiego w Polsce, Poznań 1934. 
Jaworski W., Kodeks cywilny austriacki, t. 1, Kraków 1905.

Jaworski W., Prawo cywilne obowiązujące na ziemiach polskich, Warszawa-Kraków 1919.

Kamarad E., Charakter prawny zaręczyn $w$ prawie materialnym i kolizyjnym, w: Hereditas Mercaturae. Księga Pamiątkowa dedykowanej Profesorowi Stanisławowi Miklaszewskiemu, red. Z. Mach, P. Czubik, Kraków 2012, s. 63-70.

Konic H., Prawo matżeńskie w Królestwie Kongresowym, Warszawa 1924.

Lipiński K., Odszkodowanie za niedotrzymanie obietnicy małżeństwa, „Nowe Prawo” $1954 \mathrm{nr}$ 7-8, s. 153-156.

Lisowski Z., Kodeks cywilny obowiązujący na ziemiach zachodnich RP, Poznań 1933.

Lutostański H., Zaręczyny w prawie małżeńskim z 1836 r., „Gazeta Sądowa Warszawska” 1907 nr 3, s. 34-35; nr 4, s. 48-51; nr 8, s. 111-115; nr 9, s. 123-127; nr 15, s. 221-223.

Muszalski E., Prawo cywilne obowiązujące w b. Królestwie Kongresowym, Warszawa 1932.

Pelczar S., Prawo małżeńskie katolickie, Kraków 1885.

Piasecki K, w: Kodeks rodzinny i opiekuńczy z komentarzem, red. J. Pietrzykowski, Warszawa 1993, s. 97.

Płaza S., Historia prawa w Polsce na tle porównawczym, cz. 1: X-XVIII w., Kraków 2002. Prawo cywilne. Repertorium egzaminacyjne opracowane na podstawie wykładów uniwersyteckich prof. K. Lutostańskiego i H. Konica, t. 1, Warszawa 1931.

Prawo cywilne obowiązujące na obszarze b. Kongresowego Królestwa Polskiego, red. J. J. Litauer, Warszawa 1929.

Prawo małżeńskie kościelne w porównaniu z prawem małżeńskim austriackiem według wykładów profesora dr Abrahama, cz. 1, Lwów 1911.

Prawo małżeńskie kościelne według wykładów prof. dra Ulanowskiego, Kraków 1913. Projekt prawa małżeńskiego uchwalony przez Komisję Kodyfikacyjną w dniu 29 maja 1929 r., Komisja Kodyfikacyjna. Podsekcja I Prawa Cywilnego, t. 1, z. 1, Warszawa 1931.

Pycia J., Prawo kanoniczne małżeńskie, Kielce 1922.

Rittner E., Prawo kościelne katolickie, t. 2, Lwów 1913.

Roth J., Forma zaręczyn i małżeństwa, Kraków 1908.

Rymowicz Z., Święcicki W., Prawo cywilne ziem wschodnich, t. 10, cz. 1 Zwodu Praw Rosyjskich, t. 1, Warszawa 1933.

Szer S., Zaręczyny, „Demokratyczny Przegląd Prawniczy” 1946 nr 12, s. 14-17.

Szmyd W., Praktyczny podręcznik prawa małżeńskiego, Kraków 1929.

Till E., Prawo prywatne austriackie, t. 5: Wykład prawa familijnego, Lwów 1902.

Tylbor S., Małżeńskie prawo, w: Encyklopedia prawa prywatnego, t. 3, red. F. Zoll, J. Wasilkowski, Warszawa b.r.w. 
Tylbor S., Uwagi o projekcie polskiego prawa małżeńskiego, Warszawa 1933.

Witecki J., Prawo małżeńskie. Komentarz, Łódź 1946.

Wróblewski S., Powszechny austriacki kodeks cywilny. Część pierwsza, Kraków 1914. Wróblewski S., Powszechny austriacki kodeks cywilny. Część druga, Kraków 1918.

Zasady projektu prawa małżeńskiego uchwalonego przez Komisję Kodyfikacyjną w dniu 29 maja 1929 r., opracował główny referent projektu prof. K. Lutostański, Komisja Kodyfikacyjna. Podsekcja I Prawa Cywilnego, t. 1, z. 3, Warszawa 1931. 